\title{
Development of glass ionomer cement modified with seashell powder as a scaffold material for bone formation
}

\section{Desenvolvimento de cimento de ionômero de vidro modificado com pó de conchas como material estrutural para formação óssea}

\begin{abstract}
Purpose: The present study examined the possibility of modifying the structural properties of glass ionomer cement by adding seashells to form a possible 'scaffold' material for cases of bone formation.

Methods: White and black seashells were ground into a fine, homogeneous powder. To analyze their composition, the seashell samples were submitted to EDX and X-Ray diffraction. The ground seashells were mixed with the glass ionomer cement at either 1, 5 or $10 \%$ concentrations (in weight). Samples without any seashells were used as the control group. Solutions and GIC samples were analyzed for $\mathrm{pH}$ measurement. The structural and superficial analysis of samples was performed by using scanning electron microscopy (SEM).

Results: There was no difference in $\mathrm{pH}$ values among the tested solutions with different seashell concentrations (1,5 and 10\%). In the GIC samples with the shells, the $\mathrm{pH}$ values were close to 7.0. The EDX and X-Ray diffraction showed calcium carbonate $\left(\mathrm{CaCO}_{3}\right)$ peaks for the shell samples. The superficial SEM analysis demonstrated that the samples containing seashells had framework formations in their structures.

Conclusion: Although there is a need for biocompatibility and cellular cytotoxicity testing in vitro, as well as in vivo evaluation, seashells could be used in glass ionomer cement aiming at the development of a 'scaffold' material for bone grafting or osseointegration.
\end{abstract}

Key words: Glass ionomer cement; seashells; scaffold material

\section{Resumo}

Objetivo: Este estudo examinou a possibilidade de modificar as propriedades estruturais do cimento de ionômero de vidro (CIV) pela adição de conchas para formar um material estrutural, com objetivo de uso em casos de formação óssea.

Metodologia: Conchas de cor branca e preta foram transformadas em um pó fino e homogêneo e sua composição foi analisada por EDX e difração por RX. O pó de concha foi misturado a CIV nas concentrações de 1, 5 ou 10\% (em peso) para a confecção das amostras. Amostras sem pó de concha foram usadas como grupo controle. Foram realizadas medições de $\mathrm{pH}$ de soluções do pó de conchas e das amostras de CIV. A análise estrutural e superficial das amostras foi realizada por microscopia eletrônica de varredura (MEV).

Resultados: Não houve diferença de $\mathrm{pH}$ entre as soluções testadas com diferentes concentrações de pó de concha $(1,5$ ou 10\%). Nas amostras de CIV com conchas, os valores de $\mathrm{pH}$ foram próximos a 7,0. Os métodos de EDX e difração por RX mostraram picos de carbonato de cálcio $\left(\mathrm{CaCO}_{3}\right)$ para as amostras com conchas. A análise por MEV demonstrou que as amostras com pó de conchas tinham formações estruturais diferentes do controle.

Conclusão: Embora haja necessidade de testes de biocompatibilidade e citotoxicidade celular, assim como avaliação in vivo, as conchas poderiam ser utilizadas como material de modificação estrutural do cimento de ionômero de vidro em casos de material para enxerto ósseo ou osseointegração.

Palavras-chave: Cimento de ionômero de vidro; conchas; material estrutural

\author{
Édio Giacomelli a \\ Eduardo Gonçalves Mota a \\ Hugo Mitsuo Silva Oshima o \\ Rogério Belle a \\ Luciana Mayumi Hirakata a
}

- Graduate Program in Dentistry, Pontifical Catholic University of Rio Grande do Sul, Porto Alegre, RS, Brazil

\author{
Correspondence: \\ Luciana M. Hirakata \\ Faculdade de Odontologia da PUCRS \\ Av. Ipiranga, 6681 - Prédio 6 \\ Porto Alegre, RS - Brazi \\ 90619-900 \\ E-mail: lucianahirakata@yahoo.com.br
}

Received: December 11, 2009

Accepted: November 22, 2010

Conflict of Interest Statement: The authors state that there are no financial and personal conflicts of interest that could have inappropriately influenced their work.

Copyright: (C) 2011 Giacomelli et al.; licensee EDIPUCRS. This is an Open Access article distributed under the terms of the Creative Commons AttributionNoncommercial-No Derivative Works 3.0 Unported License. 


\section{Introduction}

Researchers have been looking for alternative biocompatible materials that are able to reproduce or provide a better regeneration of lost tissue structures. For example, a large number of biomaterials have been developed as a substitute for bone tissue, such as sintered ceramics and calcium phosphate cements. GIC was introduced in the 1970s by Wilson and Kent (1) for use as a dental restorative material and adhesive composite for restorations. Because of its excellent biocompatibility with dental tissues (i.e., no records of significant adverse side effects after over 20 years of use), GICs were examined for their ability to repair bone structures (2). Glass ionomer cements are popular because they contain several important properties in an optimal dental restorative material, such as fluoride release (3), a thermal expansion coefficient and module of elasticity that is similar to the dentin (4), adhesion on both the enamel and the dentin (5) and biocompatibility $(6,7)$.

GIC originates from the neutralizing reaction between a basis of aluminum silicate glass powder, calcium, sodium fluoride and phosphate ions, and a solution of polyacids, which is generally formed by homopolymers of acrylic acid or copolymers of acrylic acid and other unsaturated acids (1). The neutralizing reaction consists of the following stages: (a) decomposition of glass components and leaching of metallic ions, (b) migration of these ions into the liquid phase, (c) configuration of the polyacid due to the interaction with metallic ions, and (d) hardening of the glass ionomer cement. Once hardened, GICs may be considered as composites of aluminum silicate glass and an inorganic bonding matrix.

In 2006, Brook and Hatton concluded that GICs are bioactive materials with osseoconduction properties, which occur through ionic exchanges of the material with the environment (9). This chemical union was described by Phillips in 1998, and it occurs through the formation of hydrogen bridges between glass particles of GIC and calcium ions in bone structure. Numerous in vitro studies assessed the biocompatibility of GICs with tissues and bone structures and demonstrated that GICs are bioactive (10-12). Ideally, in vitro evaluations should be conducted with a model that represents the clinical condition as closely as possible. Fibroblasts and osteoblasts have commonly been used to simulate clinical situations where GIC may be used. GICs have also demonstrated encouraging results in in vivo evaluations of biocompatibility and response to bony tissue. Tests conducted with GIC implantation in the femurs of mice have shown new and extensive bone formation after a 6-month period (8).

In another in vitro experiment, which utilized diffusion cameras, the surgical implant of GIC was performed in the femur of baboons right after the manipulation of the product. The authors observed that an osteoblastic reaction occurred without inhibiting the action of the GIC $(13,14)$. Jonck et al. (14) observed an inflammatory subperiostal reaction six weeks after direct or surgical application of GIC to the femurs of mice. Two factors could account for the tissue reaction: a reduction in $\mathrm{pH}$ and the release of glass particles.
The polyacrylic acid present in the GIC composition reduced the $\mathrm{pH}$, which could have caused the local tissue necrosis; however, it might not have been a serious problem for biocompatibility. Another factor that may have affected the tissue reaction was the release of glass particles that contacted soft tissues. Previous studies have documented that glass particles are released when water interacts with the GIC in its initial phase. Therefore, this is a likely cause of the inflammatory reaction on the adjacent soft tissues.

When dehydration of the GIC was observed, which leached the product's surface, there is a release of calcium, phosphate, aluminum and fluoride ions. Calcium and phosphate are valuable chemical species for the formation of hydroxyapatite, which is present in the teeth and bones. Therefore, the leaching of these elements may be beneficial. Among the leached inorganic components of the GICs, aluminum seems to be polemical. In the presence of glass ionomer cement, primary cultures of bovine osteoblasts capture and accumulate aluminum in the cells without showing any signs of toxicity (15). Fluoride release from GICs can play an important role in the mouth. In vivo and in vitro studies have demonstrated that fluoride stimulates osteoblastic proliferation, which is the reason why sodium fluoride $(\mathrm{NaF})$ is widely used in the treatment of osteoporosis $(16,17)$.

To solve the dehydration effect of GICs, hydrophilic monomers, photo-initiators and HEMA matrix have been added to the GIC composition. The addition of these products to the GICs promotes an increase of cytotoxic effects in vitro, compared with conventional GICs $(18,19)$. Oliva et al. tested the biocompatibility of 5 commercial brands of GICs in human osteoblasts and showed that conventional cements resulted in better cellular development than did resin-modified GICs (20). An alternative to reduce the deleterious effects caused by dehydration and subsequent leaching would be the use of conventional GICs after they had completed their polymerization cycle (21).

The purpose of the present study was to evaluate the possibility of using seashell powder to modify the structural properties of GICs to create a scaffold material for cases of bone formation (i.e., a special material designed to house cells or antibiotics that may be blended to the material to promote a better osseointegration).

\section{Methods}

White and black seashells were collected along the seacoast of the state of Rio Grande do Sul (Brazil), carefully cleaned and washed with distilled water. To remove all impurities, the seashells were placed in an ultrasonic tube (Ultra Sonic 1440 Plus, Odontobrás, Ribeirão Preto, SP, Brazil) with distilled water for 10 minutes. Next, they were ground into a fine, homogeneous powder in a mechanical grinder (ANM-1000, Nittokataku Co, Japan). The seashell powder was diluted to the saturation point in $100 \mathrm{~mL}$ of distilled water, and the $\mathrm{pH}$ of the saturated solution was measured. To analyze their composition, the seashell samples were submitted to EDX and X-ray diffraction. 
To select the GIC, several tests were conducted with different commercial brands and polymerization forms of the product (chemically activated, photo-activated and dual). The material that showed the best result was the conventional glass ionomer cement of chemically activated Vidrion $\mathrm{R}$ (SS White, Rio de Janeiro, RJ, Brazil - Lot 014).

The ground seashells were mixed with the glass ionomer cement powder at either 1, 5 or $10 \%$ concentrations (in weight). Samples without any seashells were used as the control group. The mixture of powder and liquid of glass ionomer cement was performed according to the manufacturer's instructions. After the reaction, the material was placed on a Teflon matrix ( $6 \mathrm{~mm}$ of diameter and $3 \mathrm{~mm}$ thick). After polymerization, the samples were removed and placed in a humidity free container where they were stored for 7 days at $37^{\circ} \mathrm{C}$.

For the $\mathrm{pH}$ measurement, the samples were ground to obtain a homogeneous powder, which was diluted in $20 \mathrm{~mL}$ of deionized water.

The structural and superficial analysis of samples was performed through scanning electron microscopy (SEM, Philips XL 30, Eindhoven, Holland).

\section{Results}

The $\mathrm{pH}$ measurements of the solutions showed that there were no significant differences between the samples. The cases presented a slight alkalinity. In the GIC samples with the shells, the $\mathrm{pH}$ values were close to 7.0. No significant differences were observed between the $\mathrm{pH}$ values of the different shell concentrations (1,5 and 10\%).

The EDX and X-Ray diffraction results showed calcium carbonate $\left(\mathrm{CaCO}_{3}\right)$ peaks for the shell samples (Fig. 1). In addition, the superficial SEM analysis demonstrated that the samples containing seashells had framework formations in their structures (Fig. 2 to 5). The framework formation in the structure of the samples seemed to be directly related to the amount of seashell powder added to the GIC (i.e., a higher percentage of shell powder showed more framework formations in the structure).

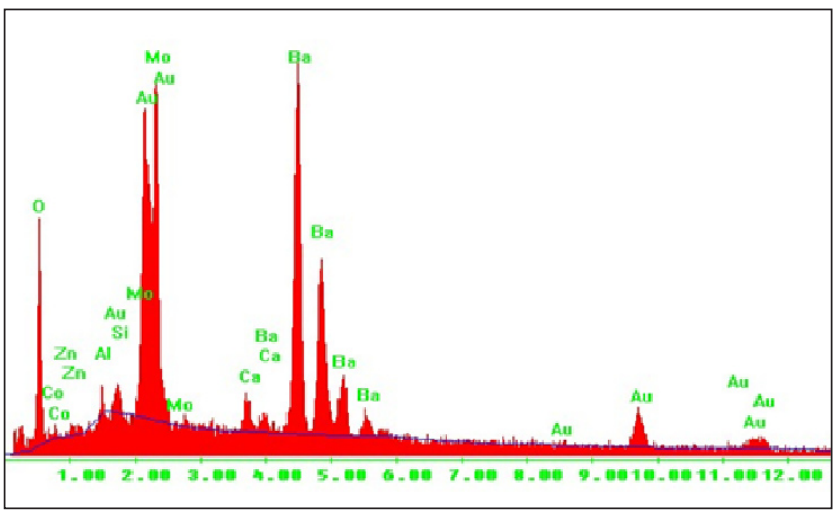

Fig, 1. EDX of seashells sample showed calcium carbonate $\left(\mathrm{CaCO}_{3}\right)$ peaks in the composition analysis.

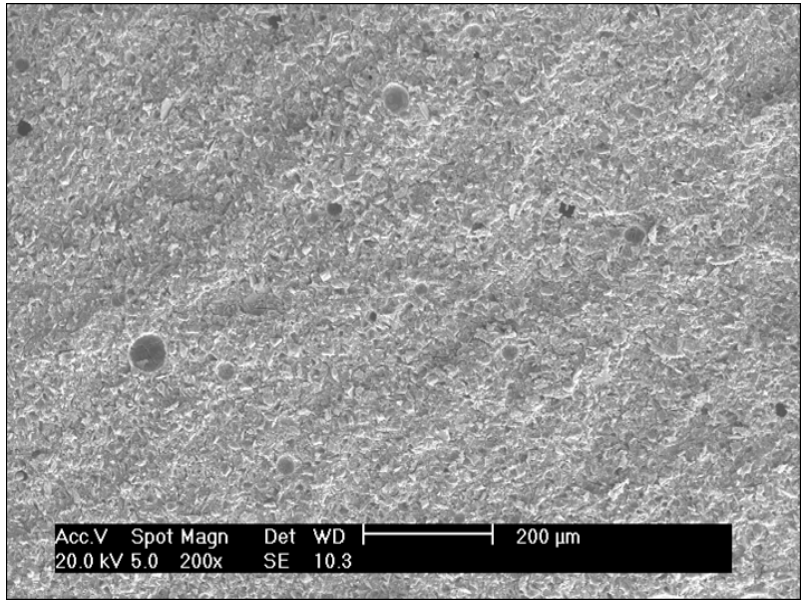

Fig. 2. SEM image of the surface of glass ionomer cement in the control group (note more regular surface, without framework formations).

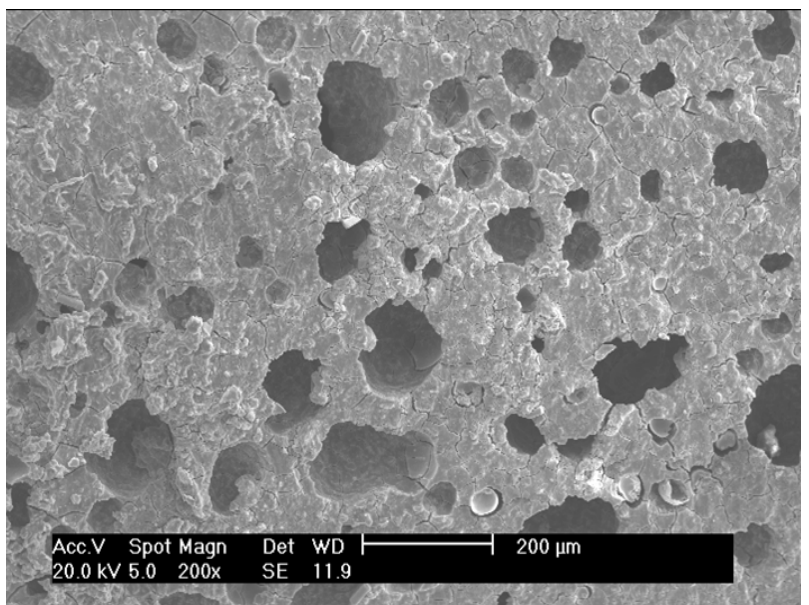

Fig. 3. SEM image of the surface of glass ionomer cement mixed with $1 \%$ seashells. Note irregularities and porosity in the material compatible with framework formations.

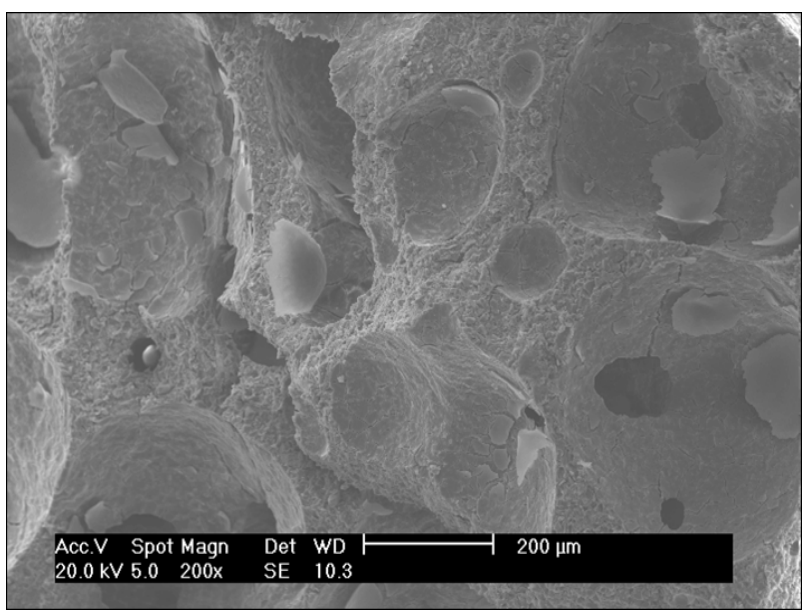

Fig. 4. SEM image of the surface of glass ionomer cement mixed with $5 \%$ seashells showing surface modification in comparison with the control group. 


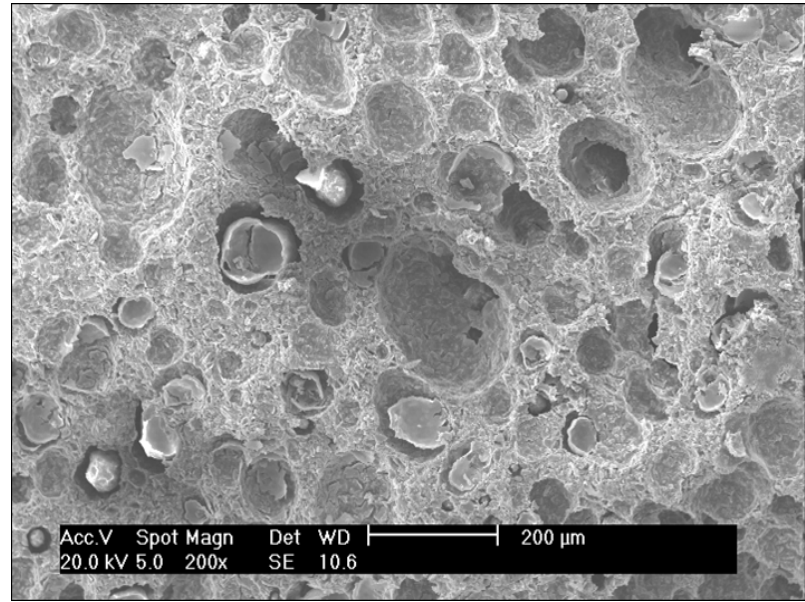

Fig. 5. SEM of the surface of glass ionomer cement mixed with $10 \%$ seashells. Note surface irregularity and inclusion of particles.

\section{Discussion}

The present study investigated the possibility of modifying glass ionomer cement with seashells to improve its properties as a bone grafting material.

There is a consensus in the literature concerning the biocompatibility and cytotoxicity of conventional GICs and GICs modified with photo-activators or HEMA matrix $(7,9,15,19)$. The adhesiveness and cellular proliferation described in the studies by Oliva et al. suggests that conventional GICs may be used as cements or implants for repairing or replacing bone tissue. Scanning electron microscopy photomicrographs showed that osteoblasts were present along the surface of the GIC (19).

The present study demonstrated that the addition of seashells to the GIC powder resulted in the formation of a framework in the samples of glass ionomer cement. Based on the SEM analysis, the framework formation was directly proportional to the amount of shells added. The formation of framework may be very important because the framework houses cells, antibiotics and other materials. In addition, the framework increases adhesiveness and cellular proliferation and improves the capacity of osseointegration of the material.

We also found an increase in the $\mathrm{pH}$ of the samples with seashells. Tests performed in shell samples showed a slightly alkaline $\mathrm{pH}(\mathrm{pH}=8)$ in both white and black shells. The $\mathrm{pH}$ of the GIC samples with the shells presented values close to neutral $(\mathrm{pH}=7)$. Because the physiological $\mathrm{pH}$ varies between 7.3 and 7.4, we may conclude that the samples will adapt to the physiologic environment; however, in vitro tests are needed to confirm this hypothesis.

\section{Conclusions}

The addition of seashell powder to glass ionomer cement could modify the material structure in order to be used as a 'scaffold' material for bone formation. However, there is a need for compatibility and cellular cytotoxicity tests in vitro and in vivo evaluation in animal models before clinical use. I Appl Chem BiotechnoZ 1971;21:313-8.

2. Wilson $A D$, Kent $B E$. A new translucent cement for dentistry. The glass ionomer cement. Br Dent J 1972;132:133-5.

3. Gao W, Smales RJ. Fluoride release/uptake of conventional and resin-modified glass ionomers, and compomers. J Dent $2001 ; 29: 30-6$.

4. Bullard RH, Leinfelder KF, Russell CM. Effect of coefficient of thermal expansion on microleakage. J Am Dent Assoc 1998;1 16:871-4.

5. Erickson RL, Glasspoole EA. Bonding to tooth structure: a comparison of glass-ionomer and composite-resin systems. J Esthet Dent 1994;6:22-44.

6. Costa CAS, Giro EM, Nascimento ABL, Teixeira HM, Hebling J. Short-term evaluation of the pulpo-dentincomplex response to a resin-modified glass-ionomer cement and a bonding agent applied in deep cavities. Dent Mater 2003;19:739-46.

7. Leyhausen G, Abtahi M, Karbakhsch M, Sapotnick A, Geurtsen W. Biocompatibility of various light-curing and one conventional glass-ionomer cement. Biomaterials 1998;19:55-64.

8. Brook IM, Hatton PV. Glass-ionomers: bioactive implant materials. Biomaterials $1998 ; 19: 56-71$

9. Hatton, PV, Hurrell-Gillingham K, Brook IM. Biocompatibility of glass-ionomer cements. J Dent 2006;34:598-601

10. Gross U, Schmitz HJ, Strunz V. Surface activities of abioactive glass, aluminium oxide, and titanium in a living environment. Ann New York Acad Sci 1988;523:21 1-26.

11. Gross U, Kinne E, Schmitz HJ, Strunz V. The response of bone to surface-active glasses and glass-ceramics. CRC Crit Rev Biocompatibil 1988;4:155-79.

12. Wallace KE, Hill RG, Pembroke JT, Brown CJ, Hatton PV. Influence of sodium oxide content on bioactive glass properties. J Mater Sci Mater Med 1999;10:697-701. 
13. Jonck LM, Grobbelaar CJ, Strating H. Biological evaluation of glass-ionomer cement (Ketac-0) as an interface material in total joint replacement. A screening test. Clin Mater 1989;4:201-24.

14. Jonck LM, Grobbelaar CJ. A glass ionomer for reconstructive surgery. lonogran - an ionomeric micro implant. A biological evaluation. Clin Mater 1992;9:85-103.

15. Meyer U, Szulczewski DH, Barckhaus RH, Atkinson M, Jones DB. Biological evaluation of an ionomeric bone cement by osteoblast cell culture methods. Biomaterials 1993;14: 917-24.

16. Kassem M, Moskilde L, Eriksen EF. Effects of fluoride on human bone cells in vitro: differences in responsiveness between stroma osteoblast precursors and mature osteoblasts. Eur J Endocrinol 1994;130: 381-6.

17. Marie PJ, De Vernejoul MC, Lomri A. Stimulation of bone formation in osteoporosis patients treated with fluoride associated with increased DNA synthesis by osteoblastic cells in vitro. J Bone Mater Res 1992;7:103-13.

18. Wilson AD. Resin-modified glass ionomer cements. Int J Prosthodont 1990;3:425-9.

19. Costa CAS, Hebling J, Garcia-Godoy F, Hanks CT. In vitro cytotoxicity of five glass-ionomer cements. Biomaterials 2003;24:3853-8.

20. Oliva A. Biocompatibility studies on glass ionomer cements by primary cultures of human osteoblasts. Biomaterials 1998;17:1351-6.

21. Cho E, Kopel H, White SN. Moisture susceptibility of resin-modified glass-ionomer materials. Quintessence Int 1995;26:351-8. 